University of New Mexico

UNM Digital Repository

Psychology ETDs

Electronic Theses and Dissertations

6-5-1937

\title{
The Relative Influence of the Locus and Mass of Destruction Upon the Control of Handedness by the Cerebral Cortex
}

La Charles Fracarol

Follow this and additional works at: https://digitalrepository.unm.edu/psy_etds

Part of the Psychology Commons

\section{Recommended Citation}

Fracarol, La Charles. "The Relative Influence of the Locus and Mass of Destruction Upon the Control of Handedness by the Cerebral Cortex." (1937). https://digitalrepository.unm.edu/psy_etds/185

This Thesis is brought to you for free and open access by the Electronic Theses and Dissertations at UNM Digital Repository. It has been accepted for inclusion in Psychology ETDs by an authorized administrator of UNM Digital Repository. For more information, please contact disc@unm.edu. 


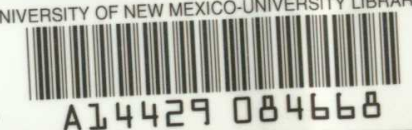


(1) 


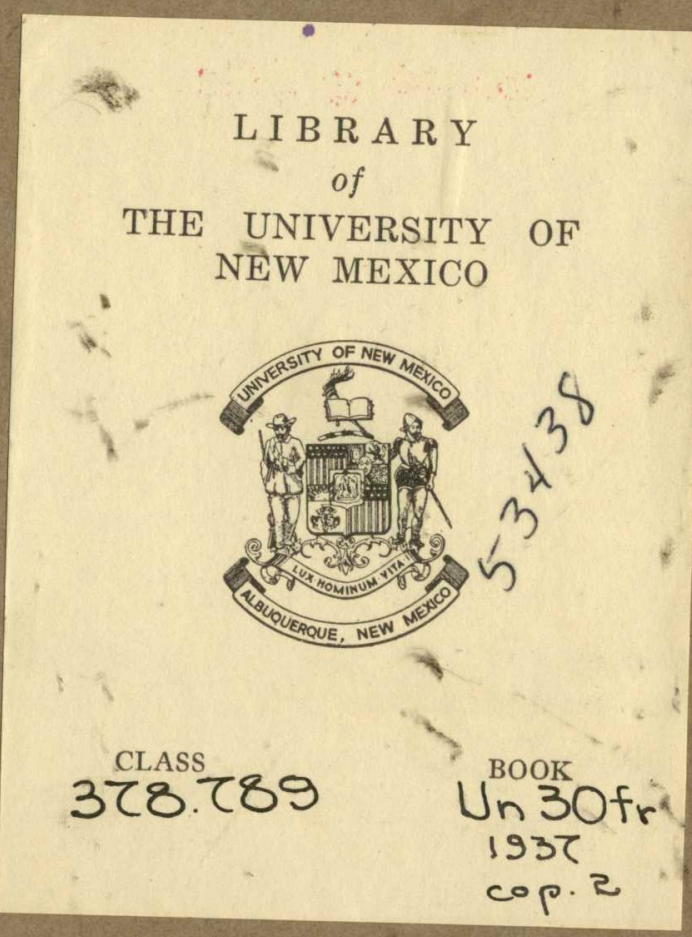




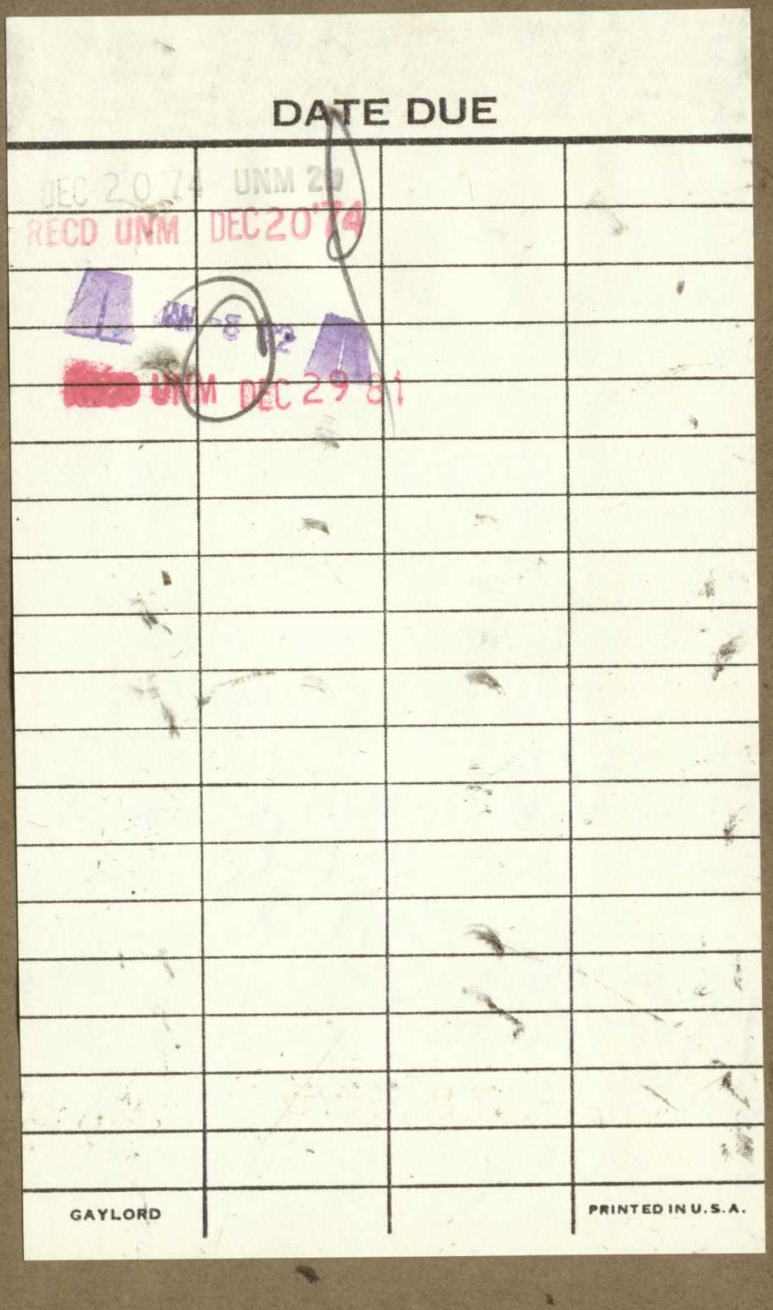





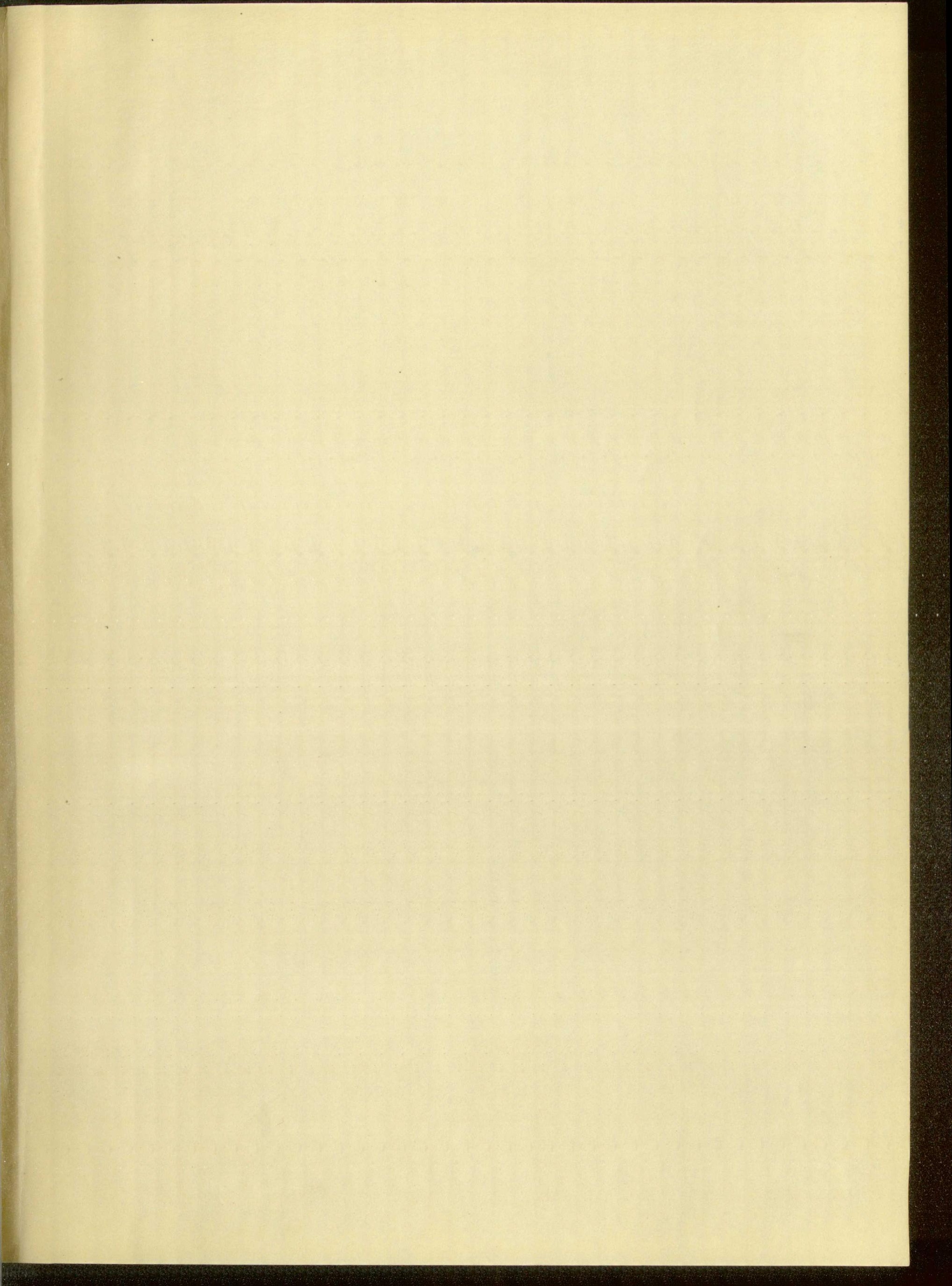




\section{UNIVERSITY DF NEW MEXICD LIBRARY}

\section{MANUSCRIPT THESES}

Unpublished theses submitted for the Master's and Doctor's degrees and deposited in the University of New Mexico Library are open for inspection, but are to be used only with due regard to the rights of the authors. Bibliographical references may be noted, but passages may be copied only with the permission of the authors, and proper credit must be given in subsequent written or published work. Extensive copying or publication of the thesis in whole or in part requires also the consent of the Dean of the Graduate School of the University of New Mexico.

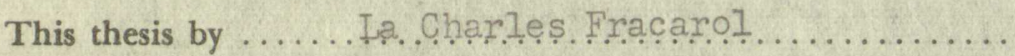
has been used by the following persons, whose signatures attest their acceptance of the above restrictions.

A Library which borrows this thesis for use by its patrons is expected to secure the signature of each user. 


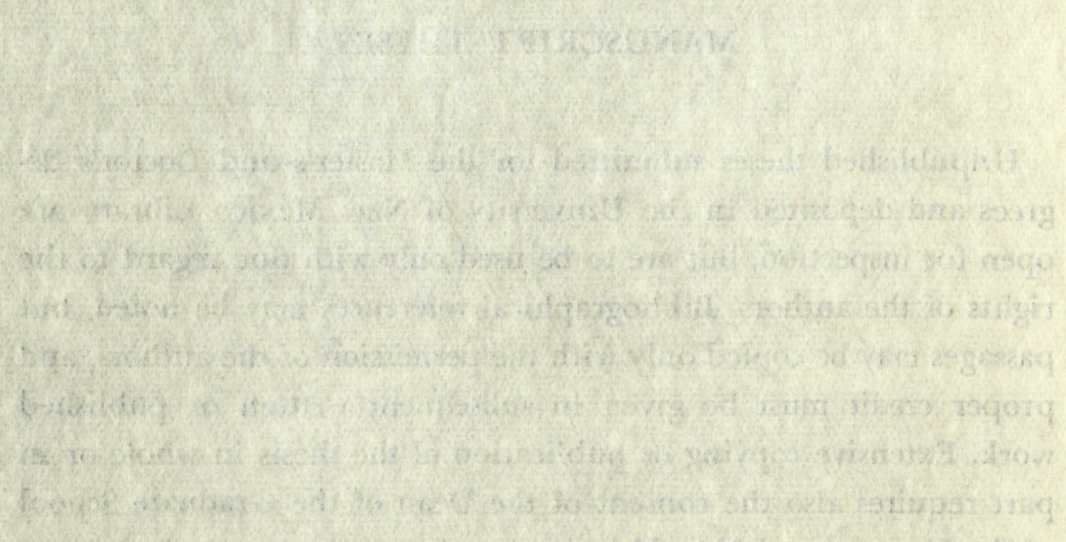

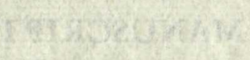

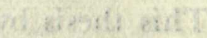

Wh.

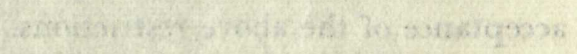

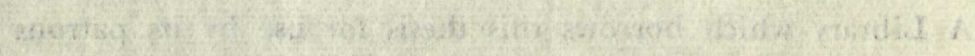

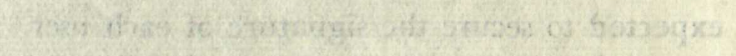
Minges:

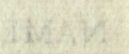




\title{
THE RELATIVR INHUUECE OF THE \\ LOCUS AND MASS OF DESTRUCTION UPON THE \\ CONTROL OF HANDEDNESS BY THE CEREBRAL CORTEX
}

By

La Charles Fracerol

\author{
A Thesis \\ Submitted in Partial Fulf1liment of the \\ Requirements for the Degree of \\ Naster of Arts in Psychology
}

University of New Mexico 
378.789

$1 \mathrm{Jn} 30 \mathrm{fr}$

1932

This thesis, directed and approved by the candidate's committee, has been accepted by the Graduate Committee of the University of New Mexico in partial fulfillment of the requiremints for the degree of

MASTER OF ARTS
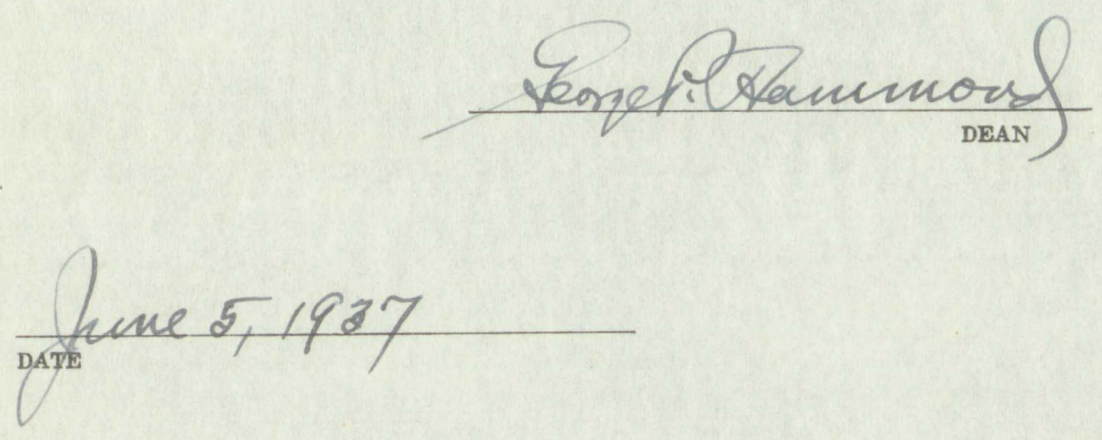

Thesis committee
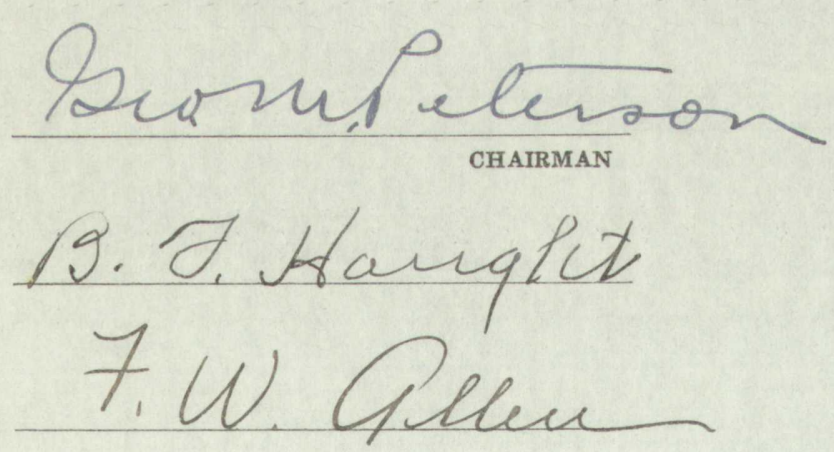

53438 


\section{ACKNOWLEDGMENT}

The writer wishes to express her gretitude to Dr. George 1f. Peterson for suggesting the problem undertaken in this study, for performing the brain operations, and for his helpful criticisms and suggestions throughout the prosecution of the study. 
TABLE OF CONTENS

CHAPTER

PAGE

I. INTRODUCTION , .........., 5

Revlew of the 11terature ....... 5

Statement of the problem ...... 8

Procedure , ........... 8

Observation methods ....... 8

Operetional techniques ....... 13

H1stolog1cal nethods........ 14

II. ANALYSIS AND INTERPRETAION OF THE DATA * 15

Generel preceutions $\ldots \ldots \ldots$........ 15

Results .............. 19

Transfer cases .......... 19

Affected cases............ 22

Non-affected cases ......... 26

III. SUMMARY AND CONCLUSIONS ....... 30

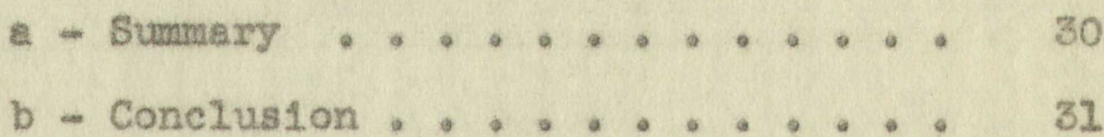

BIBLIOGRAPHY .............. 3\&

APPENDIX , . . . . . ........ 33 


\section{IIST OF TABLES}

TABLE

PAGE

I. Records on the Rellability of Fifty Hand Reaches ......... 10

II. Records on the Hendedness Consistency of Ambldextrous Rats .... 12

III. Percentage of Right-Hiandedness Before and After the Operation, Locus of the Lesion and Percentage of Destruction ........

IV. Date on Premperative and Postoperative Records in the Food Sit-

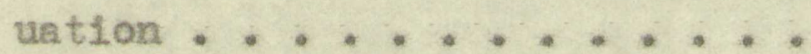




\section{CHAPTKR I}

\section{INTRODUCTION}

\section{REVIEW OF THE LITERATURE}

The doctrine of localization of function in the cerebral cortex has raised a number of interesting questions which can be answered satisfactorily only by further research. Not only is there the question of the relative loci of various functions, but also, the type of functions that have been localized, the conditions which bring about this specialization, the degree to which the specialization has occurred within a local area, the influence of adjacent regions in producing freiliatations or inhibitions, individual variations and so on. The doctrine has been criticized in recent years mainly for 1ts fallure to give an adequate account of the so called higher mentel processes. Yet even here, a more careful ansiysis besed on increasingly refined techniques has given some substantiation to certain aspects of the doctrine.

Lashley, working on the visual brightness habit hes turned in three separete reports, parts of whlch have led to somewhat diametrically opposed conceptions. The first study pointed to the occlpital cortex as the erucial area for brightness discrimination, although animals could acquire 
the habit as readily without this area. However, no one part of the occipital region appeared more important then another, and the concept of equipotentiality was accordingly suggested. 1

A reanalysis of the brightness habit followed the discovery that \& local area within the occipitel cortex was necessary for detriled vision. The reanalysis now revealed that the destruction of this area interfered with the retention of the brightness habit, but that adjacent regions contributed to the degree of loss in approximate proportion to the extent of their destruction.2

Hore recently, improved staining techniques have resulted in the tracing of pibre tracts from retine to cortex through the laters 1 genleulate nucleus and heve given a very close correspondence of parts. Brsed on this knowledge a third study of the control of the brightness hablt by the cortex revealed a high degree of localization. Partial losses in the habit (presurnably) resulting from

1 Karl S. Lashley, "Studies of Cerebrel Function in Learning. VII. The Relation Between Cerebral Mass, Leerning, and Retention," Journal of Comperative Neurology, 41: 1-58, 1926.

2 Kerl S. Lashley, "Studies of Cerebral Function in Learning. VIII. A Reanalysis of Dete on Mass Action in the Cerebral Cortex," Journal of Comparetive Neurology, 54: 80-81, Februsry, 1932 
destructions outside the eritical aree were really found to be due to amblyoplc disturbences which wide-spread destructions heve a greeter chance of producing, 3 Thus, as a rem sult of refinement in techniques, the localization theory is in good standing once more in the enalysis of visuel hebits. Nevertheless, there are other habits, noticeably the maze and latch boxes which have not been so successfully analyzed, and the question can be raised as to what part some of the alternative concepts to locelization pley in types of performance other than sensory discrimination.

Bartley ${ }^{4}$ suggested that the concept of physiological gradients might replace the doctrine of localization, and Peterson ${ }^{5}$ applying it in his study of the cerebral mechanisms of handedness concluded that the gradient hypotheses would not account for the facts "without making further assumptions." However, his cruciel analysis involved ambldextrous rats, only two of whlch were suitable for the

${ }^{3}$ Karl S. Leshley, "The Wechenism of VIsion. XII. Nervous Structures Concerned in the Aequisition and Retention of Habits Brsed on Reactions to Light, " Comperative Psychology Monographs, No. 2, 11: 60, February, 1935.

4 s. H. Bartley, "Gross Differential Activity of the Dog's Cortex as Revealed by Action Currents," Psychology. Monographs, 44: 30-56, 1933.

5 George M. Peterson, Mechanisms of Handedness in the Ret," Comperative Psychology Honographs, No. 6, 9: 36-39, Apri1, 1934. 
problem at issue, and only one of whlch was an exception to the hypothesis being tested. The present research was organized around this problem and is really en extension of the number of cases studied by Peterson.

\section{THE PROBLEM}

Statement of the problem. Speciffeally, this experiment sought an answer to the following questions:

(1) Is there evidence for a critical ares in the cerebral cortex for the control of handedness, and if so, what are the limits of this area, 1.e., what is the least destruction within this region that will produce transfers in handedness?

(2) WIII a destruetion outside of the critical. area have an effect, and if so, how large must such a destruction be to cause 1 t?

(3) What bearing will the results heve upon current theorles of cerebral functloning, Including localization of function, physiological gradients, mass action, and equipotentiality?

\section{PROCEDURE}

Observational methods. Ambidextrous rats were used, since these are essumed to be more dellcately belenced, and 
thus show trensfer effects fron minor disturbences which might be ineffective in strongly right or left handed rats. Altogether, twenty-nine ambidextrous cases were used in this study, necessitating the observation of more then 300 animals, since only about ten per cent of unselected rats are ambidextrous.

Hendedness was determined by the use of Peterson's food situation, a record being kept of the number of times each hend wes used unt1l a total of fifty reaches were taken. Severgl animbl: were observed for a longer perlod es a check to determine whether fifty reaches gave a falr sampling of the enimels preferentiel hendedness. Their records in intervals of flfty reeches are given in Table $I$. It $w 111$ be seen that the first flfty reaches give an Indication of the animals ambidexterity. In every case where flfty reaches were taken, ambidexterity is reveeled during the flrst fifty reaches and continues to be shown during successive groups of fifty reaches. However, the degree of ambidexterity shows considerable flucturtion, indicating that not too much relience can be placed upon the percentege of time one hand is used.

The animals were observed for handedness on 8 t least seven occasions before the operation. Some animals were observed for a longer period of time, and in two instances the animels were observed seventy-two times over a period of 

TABEE I

RECORDS SHOWING THE RELIABILITY

OF FIFIY HAND REACHES IN INDICATING AMBIDEXITERTTY

\begin{tabular}{|c|c|c|c|c|c|c|c|c|c|c|}
\hline \multirow{2}{*}{$\begin{array}{l}\text { Obser- } \\
\text { vation } \\
\text { period }\end{array}$} & \multicolumn{2}{|c|}{$\begin{array}{c}\text { Bet } 110 . \\
11 \text { ㅇ․ }\end{array}$} & $\begin{array}{r}\text { Rat } \\
13\end{array}$ & $\begin{array}{l}\text { No. } \\
\text { o }\end{array}$ & \multicolumn{2}{|c|}{$\begin{array}{c}\text { Ret Ho. } \\
17 \sigma^{7}\end{array}$} & \multicolumn{2}{|c|}{$\begin{array}{l}\text { Rat No. } \\
24 \sigma^{2}\end{array}$} & \multicolumn{2}{|c|}{$\begin{array}{l}\text { Rat } 100 \\
290^{4}\end{array}$} \\
\hline & RLsht & Left & alght & Teft & $21 g h t$ & Left & Reht & Left & Risht & Ifeft \\
\hline \multirow[t]{4}{*}{1} & 3 & 47 & 32 & 18 & 12 & 38 & 44 & 6 & 21 & 29 \\
\hline & 17 & 33 & 31 & 19 & 23 & 27 & 46 & 4 & 80 & 30 \\
\hline & 11. & 4 & 10 & 20 & 29 & 21 & 38 & 12 & 13 & 37 \\
\hline & & & & & 18 & 13 & 9 & 1 & 4 & 14 \\
\hline \multirow[t]{4}{*}{2} & 16 & 34 & 28 & 22 & 16 & 34 & 48 & 2 & 29 & 21 \\
\hline & 4 & 46 & 34 & 16 & 16 & 34 & 47 & 3 & 28 & 28 \\
\hline & 3 & 35 & 10 & 9 & 21 & 29 & 49 & 1 & 17 & 33 \\
\hline & & & & & 17 & 7 & & & 6 & 5 \\
\hline \multirow[t]{4}{*}{3} & & & & & 14 & 36 & 45 & 5 & 11 & 39 \\
\hline & & & & & 30 & 20 & 45 & 5 & 14 & 36 \\
\hline & & & & & 34 & 16 & 46 & 0 & 21 & 29 \\
\hline & & & & & 7 & 0 & & & 13 & 19 \\
\hline \multirow[t]{3}{*}{4} & & & & & 19 & 31 & & & $\frac{10}{12}$ & $\frac{2}{38}$ \\
\hline & & & & & 24 & 26 & & & 3 & 47 \\
\hline & & & & & 16 & 15 & & & 10 & 40 \\
\hline 5 & & & & & 21 & 29 & & & 8 & 48 \\
\hline & & & & & 26 & 24 & & & 2 & 48 \\
\hline
\end{tabular}



274 days (Nos. 1 and 2). These two cases were observed for this extended period to discover if the period selected, seven deys, was sufficlently long to give a reliable index of the animalst ambidexterity. The results of these two cases are shown in Table II. It w111 be noted that both enimals fluctuated gradually from extreme handedness to ambidexterity, and from ambidexterity to the opposite extreme. These periods of fluctuation ranged from seven days to 219 days. However, in 97 per cent of the days they were ambidextrous rather than single handed, and in no case we.s the single handedness shown for more than two successive days. Fluctuations of this sort sre encountered in cases that are definitely ambidextrous, while enimals with stronger preferences for one hrad fall to reveal such striking fluctuations. From these results it would appear that observation taken over a period of seven deys are good ind1cation of the extent of ambidexterity of rats. It occasionally happens that an animal exhibits an early ambidexterity whtch is soon overcome, whereupon he remains single handed. Rat INo. 24 is such an example, as a reference to his record In the Appendix will reveal. However, such cases always manifest these preferences relatively early, and none have been known to show it after en extended perlod of consistent 
TABLE II

RECORDS ON THE HANDEDNESS CONSISTENCY

OF ANBIDEXTROUS RATS

\begin{tabular}{|c|c|c|c|c|c|c|c|c|c|}
\hline $\begin{array}{l}\text { Obser- } \\
\text { vation }\end{array}$ & Rat I & 10.2 .9 & $\operatorname{Ret} 1$ & $\mathrm{No} .2$ 우 & $\begin{array}{l}\text { Obser- } \\
\text { vat1on }\end{array}$ & Ret N & 10.19 & Ret & 10.29 \\
\hline Perlod & R1ght & Left & P1ght & Wert & Perlod & RIght & Left & Right & Theft \\
\hline 1 & 0 & 50 & 43 & 7 & 39 & 32 & 18 & 48 & 2 \\
\hline 2 & & & 49 & 1 & 40 & 23 & 27 & 50 & 0 \\
\hline 3 & & & & & 41 & 28 & 22 & 49 & $\pi$ \\
\hline 4 & 28 & 82 & 34 & 16 & 42 & 34 & 16 & 49 & 1 \\
\hline 5 & 6 & 44 & 41 & 9 & 43 & 27 & 23 & 46 & $\frac{4}{4}$ \\
\hline 6 & & & 34 & 16 & 48 & 89 & 21 & 37 & 13 \\
\hline 7 & 35 & 37 & 44 & 6 & 45 & 32 & 18 & 24 & 26 \\
\hline 8 & 38 & 38 & 49 & 3 & 46 & 27 & 23 & 45 & 5 \\
\hline 9 & 24 & 26 & 49 & 1 & 47 & 20 & 30 & 48 & 2 \\
\hline 10 & 9 & 42 & 48 & 2 & 48 & 30 & 20 & 50 & 0 \\
\hline$\pi$ & 28 & 22 & 44 & 6 & 49 & $\frac{7}{7}$ & 43 & 50 & 0 \\
\hline 12 & & & 34 & 16 & 50 & 21 & 29 & 49 & I \\
\hline 23 & 40 & 10 & 38 & 12 & 52 & 24 & 26 & 41 & 9 \\
\hline 24 & 27 & 23 & 29 & 21 & 52 & 11 & 39 & 28 & 22 \\
\hline 25 & 36 & 34 & 28 & 28 & 53 & 19 & 31 & 67 & 3 \\
\hline 16 & 75 & 35 & 19 & 31 & 54 & 28 & 22 & 50 & a \\
\hline 17 & & & 8 & 42 & 55 & 21 & 29 & 27 & 28 \\
\hline 18 & 32 & 18 & 29 & 21 & 56 & 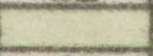 & 1 & 13 & 37 \\
\hline 19 & 27 & 23 & 26 & 34 & 57 & 42 & 8 & 22 & 28 \\
\hline 20 & 39 & 11 & 0 & 50 & 58 & 38 & 17 & 1 & 49 \\
\hline 21 & & & 14 & 36 & 59 & 36 & 14 & 44 & 6 \\
\hline 22 & 10 & 40 & 8 & 48 & 60 & 24 & 26 & 48 & 8 \\
\hline 23 & 37 & 23 & 11 & 39 & 61 & 26 & 24 & 38 & 78 \\
\hline 24 & 39 & 11 & 6 & 44 & 62 & 28 & 22 & 39 & 11 \\
\hline 25 & 36 & $\sqrt{14}$ & 30 & 40 & 68 & 15 & 35 & 19 & 31 \\
\hline 26 & 31 & 19 & 44 & 6 & 64 & 30 & 20 & 24 & 26 \\
\hline 27 & 34 & 16 & 44 & 6 & 65 & 35 & 15 & 15 & 35 \\
\hline 28 & 21 & 29 & 50 & 0 & 66 & 30 & 20 & 30 & 20 \\
\hline 29 & 44 & 6 & 47 & 3 & 67 & 14 & 36 & 24 & 26 \\
\hline 30 & 50 & 0 & 44 & 6 & 68 & 10 & 40 & 14 & 136 \\
\hline 37 & 29 & 21 & 44 & 8 & 69 & 4 & 46 & 3 & 147 \\
\hline 32 & 28 & 32 & 44 & 6 & 70 & 0 & 50 & 0 & 50 \\
\hline 33 & 32 & 18 & 17 & 33 & 72 & 0 & 50 & 6 & 44 \\
\hline 34 & 30 & 20 & 25 & 25 & 72 & 10 & 40 & 16 & 34 \\
\hline 35 & 10 & 40 & 14 & 36 & 73 & 13 & 37 & 9 & 41 \\
\hline 36 & 20 & 30 & 10 & 40 & 74 & 25 & 25 & 14 & 36 \\
\hline 37 & 24 & 26 & 21 & 29 & & & & & \\
\hline 38 & 8 & 42 & 19 & 31 & & & & & \\
\hline
\end{tabular}


ambidexterity. 6

Operational techniques. All operations were unilateral and were performed under deep ether anasthesia. Ethyl alcohol was used as an antiseptic since $1 \mathrm{t}$ is known that this chemical does not leave permanent functional effects." A one elghth inch or a one fourth inch trephine was used to open the skull for the large destructions. In a few of the small destructions a $5 \mathrm{~mm}$ drill wes used since It made sufficlently large opening to admit one wire of the cautery. Destructions in all cases were made with the thermocautery. In cases with the small drill opening only one wire could be inserted through the hole. The cautery was allowed to reach a red heat and then inserted twlce to a depth of about one elghth Inch. Seven deys were allowed for the animels to recover from the operation, whereupon they were reobserved for another period consisting of at least seven successive days, end thereafter once per week unt11 two months had elapsed. Many more observations were taken in instances where the records were

6 George M. Peterson, Mllechanisms of Handedness in the Rat", Comparstive Psychology Monographs, No. $6,9: 2-3$, Apri1, 1934.

7 George 11. Petergon and Genevieve W. Carter, "The Local Application of Drugs to the Hotor Cortex of the Rat," Journe 1 of Comperative Psvchologr, 22: 128, August, 1936. 
varisble. In four cases, Nos. $4,8,9$, and 28 , only seven post-operative observations were mede on eccount of a time shortage.

Histologicel methods. After the observations were completed the snimals were kllled and the brains removed and fixed in eleohol. They were then embedded in cellodin, sectioned fifty microns thick, snd steined with thionin. In a few cases with smoll destructions in the critical region every section was saved, but in most irstances only every fourth section was saved. Reconstructions of the lesions were mede according to Leshley's technique ${ }^{8}$ and the area of the destruction computed with a plenimeter.

8 Karl S. Leshley, Brain Mechonlsms end Intelligence (Chicago: The University of Chicago Press, 1929), pp. 16-17. 
CHAPTER II

ANALYSIS AND INTERPRETATTON OF THE DATA.

General precautions. Before analysis and interpretation of results are possible it is necessary to observe several factors which must be controlled to give reliablilty to the experiment.

(a) First, it must be recognized thet the results depend on the consistency of the records obteined in the observational periods. There can be no doubt of the reliability of a transfer in a single handed rat after a brain operation. But one eannot be so sure thet a minor chenge in an ambidextrous rat, with somewhat variable records before the operation, is of great signiflcance. Therefore, the results, in terms of percentages before and after the operation (Table III), have not been stressed. Instead, the animals have been classifled according to effect of the operation into three groups: (1) transfer eases, those which used the hand contralateral to the site of the operation less than 2 per cent of the time; (2) affected ceses, those whose hand contralateral to the site of the operation was used a swaller percentage of the time than before the operation; (3) unaffected cases, who showed no change or acturlly used the contrelateral hend more often after the operation. It was recognized that these cases might include a group with homoleteral effects.

(b) Individual variations in local areas have been 


\section{TABLE IIT}

PRRCENTAGE OF RIGHT-HANDEDNESS BEFORE AND AFTER THE OPERATION, LOCUS

OF THE IESION AND PERCENTAGE OF DESTRUCTION

\begin{tabular}{|c|c|c|c|c|}
\hline $\begin{array}{l}\text { Rat } \\
\text { No. }\end{array}$ & $\begin{array}{l}\text { Percent of } \\
\text { Right-hended- } \\
\text { ness before the } \\
\text { operation }\end{array}$ & $\begin{array}{l}\text { Percent of } \\
\text { right-handed- } \\
\text { ness after the } \\
\text { operation }\end{array}$ & $\begin{array}{l}\text { Locus } \\
\text { of the } \\
\text { lesion }\end{array}$ & $\begin{array}{l}\text { Percent of } \\
\text { Destruetion }\end{array}$ \\
\hline & $\begin{array}{r}26 \\
\end{array}$ & 100 & frontal & 12.8 to \\
\hline & 97 & 1 & frontal & \\
\hline & 14 & 99 & frontes & 16.4 to \\
\hline & 52 & 2 & fronta) & \\
\hline & 17 & 200 & occlpte & 81137.6 \\
\hline & 83 & 1 & $0 \operatorname{colp} 1$ & tal \\
\hline & 11 & 79 & occ1p1 & tel \\
\hline & 86 & 21 & occlojt & $\operatorname{tal}$ \\
\hline & 69 & 31 & ocelpit & \\
\hline & 29 & 85 & frontal & \\
\hline & 50 & 26 & fronte] & \\
\hline & 83 & 42 & frontal & 1.6 \\
\hline & 36 & 91 & pre-met & \\
\hline & 10 & 68 & pre-mot & tor \\
\hline & 40 & 64 & pre-mot & tor \\
\hline & 95 & 68 & pre-mot & tor \\
\hline $\mathrm{F}$ & 2 & 11 & pre-mot & tor 5.2 to \\
\hline & 84 & 96 & frontal & \\
\hline $21 \mathrm{~F}$ & 98 & 99 & fronts? & 18 \\
\hline & & & $00 \mathrm{celp1}$ & $\operatorname{tal} 135.6$ \\
\hline 3 & 96 & 100 & Irontes & 28 \\
\hline & & & $\operatorname{occ} 101$ & tal \\
\hline & 97 & 99 & occlpil & $\operatorname{tal}$ \\
\hline & 99 & 100 & $\operatorname{acclp} 11$ & $\operatorname{tal}$ \\
\hline & & & occipit & t8] \\
\hline & 95 & 100 & $0 \operatorname{ectp11}$ & ta] \\
\hline 5 & 95 & 97 & $\operatorname{acc} 1 p^{11}$ & tal \\
\hline 8 II & 74 & 89 & ocelp1 & taI \\
\hline 2911 & 18 & 3 & 000101 & t8I \\
\hline
\end{tabular}


Irequently reported in the 1iterature. Peterson has mentioned variations within the electro-stimuleble region in the rat. 9 Lashley has found conslderable variation of the area striate from one animal to another, fnd has suggested thet such variations are the result both of anstomicel differences and of changed in physiological organization.10 Any attempt to localize a function precisely by means of a common area of several transfer cases is defeated if such variations are too great. Such common areas reduce themselves to zero, and we would be forced to conclude that there wrs no locallzation of function. Yet, every transfer case may be within a few millimeters of some such locus, while the uneffected cases are considerably farther removed. Thus we are forced to admit a speclalization of function within the cerebral cortex, withal the possibility of variation of any precise locus from one animal to another.

(c) Cortical. laminstion presents another type of speclalization which must be considered in the analysis of the results. According to Cralgie, the large pyramidal tract are found in layer $V$ of the rat cortex. ${ }^{11}$ If corticel transfers result only from injuries to this mechenism, then lesions invading more superflcial layers of the cortex might have no influence on the handedness. Thus, the depth as well as the

9 George M. Peterson Mllechanisms of Hendedness in the Ret, " Comperetive Psychology Monographs, No,6, 9: 23-24, Apri1, 1934

10 Kar1 5. Lashiey, Brain Mechenisms and Intelligence (Chicago: The University of Chicago Press, 1929), p. 24.

11 B. Horne Craigie, An Introduction to the Finer Anstomy of the Central Hervous System Besed Unon That of the Anino Rat (Philadelphia: P. Blakeston's Sons and Compeny, 1925), p. 111. 
extent of the destruction must be taken into consideration.

(d) It is difficult to interpret subcortical inJuries because of our Ignorance regerding the part played by varlous subcortical mechanlsms on hendedness. The subcortical mechanisms most frequently invaded in this study were the hippocampus, caudate nucleus, and thalamus. Hippocampal injuries are assumed to be ineffective in causing trensfers, both for anatomicel reesons, and because too many injurles of this type have falled to show effects. This cannot be said for the caudate nucleus and thalamus, and it is possible that transfers in some instances could be due to injuries to the subcortical structures rather then to a destroyed locus of the cerebral cortex. Less welght must be given to such ceses in the interpretetion of the results. An attempt to interpret results in the light of the size of the pyramidal tract in the cerebral peduncles gave negative results, since some cases, showing an obvious reduction in size falled to transfer in handedness, and other transfer cases falled to reveal a not1ceable difference in size. This was to be expected since the tact carries flbers other than those specialized for hand and arm movements, but the attempt was made in an effort to control subcortical influences.

(e) Another factor which gives some difficulty in 
the precise localization of a critical area, is the inaccuracy of the brain charts used in plotting the lesions. The particular chart used is probably more in error in the frontal than the occipital regions, and it is in the frontal region that there is need of greatest accuracy. Lashley's new chart would be preferable, but it wes not avallable soon enough for this study, and it is doubtful if any chert would be wholly satisfectory since individual differences in brain size would elways produce some deviations. An attempt was made to overeome this difficulty by an analysis in which the brain sections themselves were examined under overlapping conditions at comprable levels. The results thus obtalned were used to supplement those results obtalned from an anelysis of the overlapping lesions outlined in the brsin charts.

The percentage of right hondedness before and after the operation, the locus and the extent of the destruction are given in Table III; the Individual hendedness records both before and after the operation are given in Appendix.

Results. The results of the operation are divided Into the following cases: transfer cases; effected cases; and unsfected cases.

Trensfer ceses. Fight eases transfered (Nos. 3, 4, $5,6,7,8,9$, and 10). Four of these involved frontal destructions (Nos. $3,4,5$, and 6 ), and four occipital 
destructions (Nos. 7, 8, 9, and 10). Of the frontal cases, No. 6 is especislly noteworthy because of the small aree of destruction, less than 1 per cent, which produced a transfex.

If a composite of the common area for all the transfer cases is drawn, the ares completely vanishes because of rat No. 7, whose destroyed area had nothing in common with the rest of the transfer cases. A composite of the four frontel cases gives a common area which is shown in black in Figure I; the total area for all four cases in in out11ne. This common ares 1 s at level nine on the chart, and Iles directly above the dorsal aspeet of the caudate nucleus. It is 250 microns posterior to the gemu of the corpus callosum. A comparison of the four occipital transfer cases with the comon area of the frontel cases reveals that three of them (Nos. 8,9, and 10) include all of 1t. The remeining ease, No. 7 , did not involve this common erea, but a consideration of the subcortical invasion of this case reveals that the dorsal convexity of the eaudete nucleus has been definitely invaded, especialiy in the region of level eleven. Even if the caudete nucleus itself were not determining factox in handedness, 1 ts invasion would more then Ilkely cut the pyramidal fibers coming from the region of level nine and lnvolving the criticel area for handedness. With the exception of this animal, the destructions 
F1g. 1. A composite of four frontal transfer cases (Nos. $3,4,5$ and 6 ) with the common area show in black. 
of al1 seven cases were deep enough to include layer $V$ of the cortex and, st some parts of the lesion, included all six layers of the cortex.

One case, No. 11, with an ocelpital Iesion which did not involve the common area, showed a temporery transfer with subsequent recovery. This temporary transfer may have been due to a blood clot or pressure on the cortex which gradually disappeared.

Transfers that occur from lesions in the ocelpital cortex could be due to an Invasion of the local area, or to the destruction of pyramidal fibers descending from this area. It is diffieult to explein them by the extent of the destruction. The smallest occipltal lesion that caused transfer was 30 per cent of one hemisphere in rat No. 10 ; case No. 21, which did not trensfer, had a lesion which closely overlapped that of No. 10, amounting to 36 per cent of the hemisphere. Such facts do not conform with mass or gradient theorles of cortical funetioning.

Affected cases. There were elght affected ceses (Nos. $12,13,14,15,16,17,18$, end 19) in which the degree of transfer ranged from very marked to very $\mathbf{s i g h t}$ disturbence. In view of the minor fluctuetions in ambldexterity, the latter cases could be regarded skeptically, but this is hardly true of the ceses showing more merked changes. Since these cases are evidently not due to the 
unrellability of ambidexterity, it is assumed that these very slightly disturbed cases also indicete reliable chenges as a result of the operation. Three animals in the affected group have lesions which partly invade the eritical area (Nos. 12, 13, and 14). In one of these cases, No. 12, the contralateral hand was used about 15 per cent of the time after the operation. Its destruetion, although somewhat larger, involved the same region of the cortex as rat No. 6, which used his affected hend only 2 per cent of the time. Both of these cases were very evenly divided in the use of their hands before the operation. The individurl differences In these two cases are difficult to account for the present time. The other two cases (Nos, 13 and 14) did not involve all of the eritieal area and their partial transfers could be accounted for by this fact; agrin, since they involve about the same amount of the critical aree, the differences In their degree of transfer might be due to the fact that the one which showed the lesser effeet was less ambidextrous before the operation.

Five cases with lesions considerable anterior to level nine were also affected (Nos. 15, 16, 17, 18, and 19). There are not enough cases here to offer an adequate study of the relative influence of the locus, distance from the critical area, size of the lesion, or the degree of ambidexterity before the operation, in determining the degree 
of transfer whlch occurred. But there is an exception to the possiblilty that any one of these factors taken alone is the determining factor in producing the effect, if it were dependent on the degree of ambidexterity. Rat Nos. 15 and 17 should be more affected then Nos. 16 and 18, whereas they were influenced to a lesser degree by the operation. Similarily, if it were a function of mass, Nos. 17 or 19 with greater destructions should be more affected than No. 15 with the smellest destruction, but in $\mathrm{r}$ eality No. 15 showed the greeter effect. Again, if 1t were dependent upon 1ts proximity to the eritical region Nos. 15 and 16 should be less affected then Nos. 17 and 18, but they were actually more affected.

There are two other possibilities which may be considered. Flrst, these cases might delimit a secondery handedness aree, a sort of "premotor" cortex, in the vieinity of level five whlch acts as a faclitating mechenism upon the criticel aree. This seems unlikely since Lashley found that the entire frontal pole is electrically stimulable. ${ }^{1}$ If a region that gives hend and arm movements when stimulated electricelly turns out to be specilized for the control of these orgens, should we not expect that another region which gives

\footnotetext{
IKarI S. Leshley, "Tho Motor Arees," Brain, 4: $255-258,1921$.
} 
head or neck movements to be speclalized for the control of these parts?

Secondly, frontel operations might interfer with the circulation of the blood through the anterior cerebral artery and thus disturb metabolism in the region of level 9. This eppesrs less plausible when we remember that shallow lesions in the neighborhood of level 9 ere Ineffective if they do not invade layer $V_{2}$ yet they unquestionably disturb the superficial blood circulation. Apparently, more critical date are necessary to interpret these $r$ esults.

However, these cases as a group present strong evidence in favor of a "more or Less" type of functioning rether than an "all or none" type suggested by Lashley in his recent study of the visual cortex. ${ }^{2}$ This "more or less" functioning of a region was elso noted in the case of gradual transfers and recoveries previously reported. 3 It is again possible to see a preferent1al use involving two mechanisms.

2 Karl S. Iashley, "The Mechanism of Vision. XII. Nervous Structures Coneerned in the Acquisition and Retention of Habits Based on Reactions to light, " Comparative Psychology Monogrephs, No. 2, 11: 74, February, 1935.

3 Ceorge II. Peterson, "rechenisms of Handedness in the Ret, Comparative Psychology Manographs, No. 6, 9: 39, Apr11, 1934. 
Non-affected eases. Three ceses with frontel operations (Nos. 20, 21, and 22), two of whleh also had oecipital lesions (Nos. 21 and 22), and seven other cases with occipital lesions (Nos, 23, 24, 25, 26, 27, 28, and 29), were not affected by the operation. That is, these cases used their contreleteral hands at least as often 8 before the operation. The lesions of the three frontal cases were very shellow, none of them invading deeper than the third layer of the cortex. In one of these cases, No. 20 , the lesion unquestionably involved all of the eritical area, and was sufflclently large ( 7.6 per cent) to have produced a trensfer. The other two cases, Nos, 21 and 23, possessed large enough oeclpital lesions, 35.6 and 29.2 per cent, and enough of the eritical area to have had an affect on their hendedness on the besls of the results previously described. We mey, therefore, assume that the cells which must be disturbed to produce transfers are below layer III and are probably the large pyramidal cells of layer $V$ whose fibers form the pyramidel tract.

Two of the nine cases with occipltel lesions, Mos. 21 end 23, lnvolved parts of the eritical aree and were sufficlently deep to inelude layer $\mathrm{V}$. It is somewhat surprising that they did not at least show an effect. However, since the eritical area was oniy partially invaded, 
we can assume elther that enough of it remained intact to carry out the handedness function, or that there was sufflcieat displacement of the area in these two cases to make it less Invaded than the microscopleal analysis seemed to indicate: In other words, that these cases furnish two examples of individual variations.

The remalning occipital cases, Nos. 22, 24, 25, 26, 27, 28, and 29, were not influenced by the operation, or were influeneed in the wrong direetion, that is, they used thelr contralaterel hands more often. Such a ehange could be regarded as a "homoletera " or Inhibiting effect, in opposition to the contralateral or facllitating effect revealed by the frontal cases. This interpretation, however, can be regarded very skeptlcally for the following reasons. Seven of the occipital cases (Nos, 21, 22, 23, 24, 25, 26, and 27) were very s.1ghtly ambidextrous preferring one hand 95 per cent of the time, or more, before the operation, and revealling periods when they used one hend exclusively. Their change after the operation could be continuation of this and thus lack significance from the stand point of an operational influenee. Furthemore, a detelled examination of the two cases which were markedly affected (Nos. 28 and 29) reveals that they have somewhat veriable records. Thus, although No. 28 used his left hend 26 per cent of the time on nine occasions before the 
operation, he used 1t less than 10 per cent of the time on three of these occasions, which approximates his record after the operation. S1milar1y, No. 29 used his right hand only about 5 per cent of the time during the last six pertods before the operation, elthough he used it an average of 18 per cent of the time throughout this period. Fis change to 3 per cent usage after the operation is not far out of line from this 5 per cent usage and henee less significant than if compared to his complete record. Finally, Rat No, 20 with shallow frontal destruction may also have shown this homolateral or inhtbitive effect, but again hts chenge is in accord with his more recent record before the operation. Therefore, whlle all these cases may reveal such an effect, they are not declsive enough to be offered as conclusive evidence.

They are, however, strong evidence egainst any non-1ocallzation theory which essumes that all regions of the cerebral cortex function as a whole in the control of behavior. If the occipital cortex contributed a meas influence or portion of a physiological gradient, the destructions would be expected to heve a more or less effect on hendedness, as happens with frontal injurles. The results obteined in these cases also make $1 t$ obvious that the transfers occurring from the extensive destructions In ceses $7,8,9$, and 10 were due to the invasion of the 
critical region or 1 ts underlying fiber tricts, and not to a destruction outside this frontal region. 


\section{CHAPTHE III}

\section{SURMAPY AND CONCLUSIONS}

Twenty-seven embidextrous rats were subjected to a varlety of cerebral operetions malniy in. the frontel and occipital cortex for the purpose of studying the relet1ve influence of the locus and mess of destruction upon changes in handedness. Two additional rats were observed over a long time period to determine if embidexterity 18 a surflciently rellable index to be used as a orlterion in a study of the cerebral control of this tra1t. The results Indicate that. elthough there are fluctuations and changes in the use of the hends by embidextrous rets, the animels are sufflelently consistent to warrant the conclusion that persistent changes after cerebral extirpations are due to the operstions and are not fortuitous, chance occurrances.

It was furthermore found that a smell region in the contralateral frontal lobe is essential for the control of hentedness by the eerebral cortex. This region is approximately 250 microns posterior to the genu of the corpus callosun, directly over the dorsal convexity of the caudete nucleus, and lies below loyer III of the cortex,

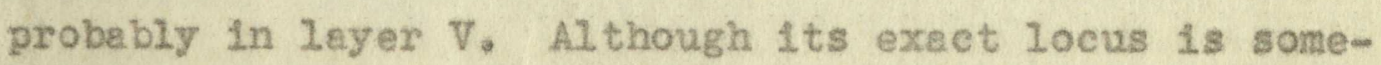
what variable from one enimal to snother, extirpations in 
this region result in marked chenges in the use of the hend, Injuries to other parts of the frontal lobe also influence the preferentiel use of the hands, but less markedly then destructions in this criticel eres. If such injuries are evidence for a facllitating function of the reminder of the frontal lobe, the conditlons producing it are not reveeled.

Infuries in the occipltal and parts of the temporal region have no such effect upon the use of the hands. In fect, if these regions meke eny contribution to the control of this trait, it is an opposite effect to thet expected; that is, the animels use their contralaterel hands more often after such operations. Thet they contribute nothing to the control of the hablt is clearly seen in the fallure of these occlpital injurles to produce more or less effect as some of the frontel injuries did even when complete transfers did not result. The effects obtelned from such occipltal operetions as were influentidi cen be attributed to the Invesion of the eriticel sree or to the seversnce of Plber trects which form the pyremidel system and descend from this area.

The results are compatible with locelization theories of cerebrel functioning but not with non-locklizetion theorles, such as mess ection, equipotentielity, physiologicel gradients, ete. 
From the results obtained, the following conclusions are drewn:

(1) Amb1dexter1ty affords a sufficiently erit1cal and reliable means of Investigating the functioning of the cerebral cortex.

(2) The trait of handedness is under the control of a highly localized mechanism in the frontal region of the cerebral cortex, and large destructions outside the frontal lobe are ineffective in producing changes in th1s tra1t.

(3) The results support a locallzation theory and are in opposition to current non-locelization theorles. 
BIBII OGRAPHY 


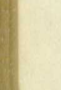




\section{BIBLIOGRAPHY}

Craigle, E. Horne, An Introduction to the Finer Anatomy of the Central, Nervous Srster Besed Upon That of the Albino Rat. Philadelphia: P. Bladeston's Sons and Company, 1925. 127 pp.

Lashley, Karl S., "The Wotor Areas," Brain, 44: 255-285, 1921.

- "Studies of Cerebral Function in Learning. VII. The Relation Between Cerebral Mass, Learning, and Retention, Journal of Compsrative Neurologr, 4I: $1-58$, 1926.

- Brain Mechanisms and Intelligence. Chicago:

The University of Chicago Press, 1929. 186 pp.

- "Studies of Cerebral Function in Learning. VIII. A Reanelysis of Deta on llass Action in the Cerebral Cortex," Journel of Comparative Neurology, 54: 77-84, February, 1982.

WThe Mechenism of VIsion. XII. Nervous Structures Concerned in the Acquisition and Retention of Habits Based on Reactions to Light, ${ }^{n}$ Comperative Psychology Monogrephs, No. 2, 11: 43-79, February, 1935.

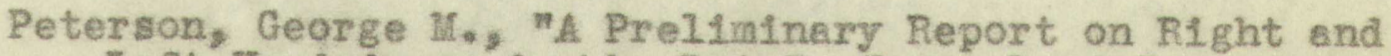
Left Handedness in the Rat," Journal of Comperative Psycholorx, 12: 243-250, August, 1931.

mMechanisms of Hendedness in the Rat," Comparative Psychology Monographs, Ho. 6, 9: 1-67, April, 1934.

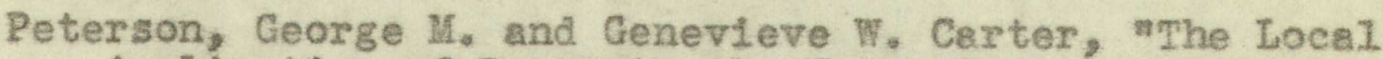
Application of Drugs to the Motor Cortex of the Rat, Journel of Comperetive Psycholosy, 22: 123-129, August, 1936. 


\section{APPENDIX}



APPENDIX

TABLE IV

RECORDS IN THE FOOD SITUATTON

\begin{tabular}{|c|c|c|c|c|c|c|c|c|c|c|}
\hline $\begin{array}{l}\text { Obser- } \\
\text { vation }\end{array}$ & $\begin{array}{r}\text { Ret } \\
3\end{array}$ & $\begin{array}{l}\text { No. } \\
\text { \&. }\end{array}$ & $\begin{array}{r}\text { Ret } \\
4\end{array}$ & $\begin{array}{l}\mathrm{No}: \\
7\end{array}$ & $\begin{array}{r}\text { Rat } \\
5\end{array}$ & $\begin{array}{l}\text { No. } \\
9\end{array}$ & $\begin{array}{r}\text { Rat } \\
6\end{array}$ & $\begin{array}{l}\text { No. } \\
9^{9}\end{array}$ & $\begin{array}{r}\text { Ret } \\
7\end{array}$ & $\begin{array}{l}\text { No. } \\
7^{\circ}\end{array}$ \\
\hline period & Ight & Ieft & Right & Lert & IIght & Geft & dight & Left & $18 h t$ & weft \\
\hline 1 & 9 & 41 & 48 & 2 & 16 & $\sqrt{34}$ & 27 & 23 & 14 & 36 \\
\hline 2 & 26 & 24 & 46 & 4 & 0 & 150 & 23 & 27 & 15 & 35 \\
\hline 3 & 4 & 46 & 47 & 3 & 19 & 31 & 42 & 8 & 6 & 44 \\
\hline 4 & 32 & 18 & $4 \gamma$ & 3 & 4 & 146 & 29 & 21 & 0 & 50 \\
\hline 5 & 40 & 10 & 50 & 0 & 0 & 50 & 32 & 18 & 8 & 47 \\
\hline 6 & 0 & 50 & 50 & 0 & 5 & 145 & 4 & 46 & & \\
\hline 7 & 5 & 45 & 50 & 0 & 8 & 42 & 21 & 29 & & \\
\hline 8 & 7 & 43 & 50 & 0 & 10 & 40 & 22 & 28 & & \\
\hline 9 & 10 & 40 & & & 7 & $\longdiv { 4 3 }$ & 32 & 18 & & \\
\hline 10 & 0 & 50 & & & 8 & 142 & 30 & 20 & & \\
\hline 11 & 10 & 40 & & & 2 & 48 & 27 & 23 & & \\
\hline 12 & 15 & 35 & & & 5 & 45 & 25 & 25 & & \\
\hline & & & & & & & & & & \\
\hline
\end{tabular}


APPENDTX

TABLE IV (eontinued)

POST-OPERATIVE RECORDS IN THE FOOD SITUATION

\begin{tabular}{|c|c|c|c|c|c|c|c|c|c|c|}
\hline $\begin{array}{l}\text { Obser- } \\
\text { vetion }\end{array}$ & $\begin{array}{r}\text { Ret } \\
3 \\
\end{array}$ & $\begin{array}{l}\text { No. } \\
+ \\
\end{array}$ & $\begin{array}{r}\text { Rat } \\
4 \\
\end{array}$ & $\begin{array}{l}\text { No. } \\
+\end{array}$ & $\begin{array}{r}\text { Rat } 1 \\
5 \% \\
\end{array}$ & $\begin{array}{l}\text { No. } \\
q^{2}\end{array}$ & $\begin{array}{r}\text { Ret } \\
6 \\
\end{array}$ & $\begin{array}{l}\text { No. } \\
\text { o }\end{array}$ & $\begin{array}{r}\text { Rat } \\
7 \\
\end{array}$ & $\begin{array}{l}\text { No. } \\
\text { q }\end{array}$ \\
\hline period & 11ght & Left & Ight & beft & ilght & Geit & Right & Left & Right & Iheft \\
\hline 1 & 50 & 0 & 1 & 49 & 50 & 0 & 18 & 132 & 50 & 0 \\
\hline 2 & 50 & 0 & 0 & 50 & 50 & 0 & 3 & 49 & 50 & 0 \\
\hline 3 & 50 & Q & 0 & 50 & 50 & 0 & 2 & 48 & 50 & 0 \\
\hline 4 & 50 & 0 & 0 & 50 & 49 & 1 & 0 & 50 & 50 & 0 \\
\hline 5 & 50 & 0 & 0 & 50 & 49 & 1 & 1 & 49 & 50 & 0 \\
\hline 6 & 50 & 0 & 0 & 50 & 49 & I & 0 & 50 & 50 & 0 \\
\hline 7 & 50 & 0 & 0 & 50 & 50 & a & 1 & 149 & 50 & 0 \\
\hline 8 & 50 & 0 & & & 50 & 0 & $I$ & 148 & 50 & 0 \\
\hline 9 & 50 & 0 & & & 50 & 0 & 0 & 50 & 50 & 0 \\
\hline 10 & & & & & & & 0 & 50 & 50 & 0 \\
\hline 11 & & & & & & & 0 & 50 & 50 & 0 \\
\hline 12 & & & & & & & 0 & 150 & 50 & 0 \\
\hline 23 & & & & & & & 0 & 150 & 50 & 0 \\
\hline 14 & & & & & & & 0 & 150 & 50 & 0 \\
\hline 75 & & & & & & & 0 & 150 & 50 & 0 \\
\hline 16 & & & & & & & 0 & 150 & 50 & 0 \\
\hline 17 & & & & & & & 0 & 50 & 50 & 0 \\
\hline 18 & & & & & & & 3 & 149 & & \\
\hline 9.9 & & & & & & & 1 & 149 & & \\
\hline 20 & & & & & & & 0 & 50 & & \\
\hline 21 & & & & & & & 0 & 150 & & \\
\hline 22 & & & & & & & 0 & 150 & & \\
\hline 83 & & & & & & & 0 & 50 & & \\
\hline 24 & & & & & & & 2 & 148 & & \\
\hline
\end{tabular}




\section{APPENDIX \\ TABLE IV (continued) \\ RECORDS IN THE FOOD SITUATION}

\begin{tabular}{|c|c|c|c|c|c|c|c|c|c|c|}
\hline $\begin{array}{l}\text { obser- } \\
\text { vation }\end{array}$ & $\begin{array}{r}\text { Ret } \\
8 \\
\end{array}$ & & $\begin{array}{r}\text { Ret } \\
9 \\
\end{array}$ & & $\begin{array}{l}\text { Ret } \\
10,5 \\
\end{array}$ & & $\begin{array}{l}\text { Ret } \\
1 I \\
\end{array}$ & $\begin{array}{l}\text { No. } \\
\text { iq }\end{array}$ & $\begin{array}{l}\text { Ret } \\
12,\end{array}$ & $\begin{array}{l}\text { 110. } \\
q\end{array}$ \\
\hline period & Right & ieft & Ight & Left & Sight II & Geft & RIght & Left & RIght & Left \\
\hline 1 & 41 & 9 & 8 & 42 & 29 & 21 & 15 & 35 & 23 & 27 \\
\hline 2 & 45 & 5 & 6 & 44 & 34 & 26 & 3 & 47 & 10 & 40 \\
\hline 3 & 45 & 5 & 9 & 41 & 46 & 4 & 16 & 34 & 10 & 40 \\
\hline 4 & 39 & 11 & 6 & 44 & 49 & $I$ & 25 & 25 & 3 & 47 \\
\hline 5 & 43 & 7 & 8 & 42 & 48 & 2 & 29 & 21 & 8 & 42 \\
\hline 6 & 39 & 11 & 2 & 48 & 39 & II & 47 & 3 & 10 & 40 \\
\hline 7 & 37 & 13 & 4 & 46 & 47 & 3 & 48 & 2 & 12 & 38 \\
\hline 8 & 44 & 6 & 0 & 50 & 50 & 0 & 46 & 4 & 5 & 45 \\
\hline 9 & & & & & & & 11 & 39 & 13 & 37 \\
\hline 10 & & & & & & & 46 & 4 & 13 & 37 \\
\hline 11 & & & & & & & 49 & $\Rightarrow$ & 17 & 38 \\
\hline 22 & & & & & & & 36 & 14 & 18 & 32 \\
\hline 18 & & & & & & & 42 & 8 & 21 & 29 \\
\hline 14 & & & & & & & 44 & 6 & 21 & 29 \\
\hline 15 & & & & & & & 49 & $I$ & 26 & 24 \\
\hline 16 & & & & & & & 48 & 2 & 22 & 28 \\
\hline 17 & & & & & & & 49 & 1 & & \\
\hline 18 & & & & & & & 27 & 23 & & \\
\hline
\end{tabular}


APPENDIX

TABLE IV (continued)

POST-OPERATIVE RECORDS IN THE FOOD SITUATION

\begin{tabular}{|c|c|c|c|c|c|c|c|c|c|c|}
\hline $\begin{array}{l}\text { Obser- } \\
\text { vation }\end{array}$ & $\begin{array}{r}\text { Ret } \\
8 \\
\end{array}$ & $\begin{array}{l}\text { No. } \\
0^{\prime}\end{array}$ & $\begin{array}{r}\text { Fat } \\
9 \\
\end{array}$ & $\begin{array}{l}10 . \\
0^{2}\end{array}$ & $\begin{array}{r}\text { Fet } \\
10 \\
\end{array}$ & $\begin{array}{l}\text { No. } \\
0^{2}\end{array}$ & $\begin{array}{r}\text { Rat } \\
11 \\
\end{array}$ & $\begin{array}{l}\text { No. } \\
\text { 9. }\end{array}$ & $\begin{array}{r}\text { Rat } \\
12 \\
\end{array}$ & $\begin{array}{l}\text { No. } \\
\text { q }\end{array}$ \\
\hline perlod & RIght & Left & Right & Left & Right & Left & Right & Left & Right & Left \\
\hline 1 & 0 & 50 & 6 & 44 & 49 & 1 & 0 & 50 & 38 & 12 \\
\hline 2 & 0 & 50 & 21 & 29 & 50 & 0 & 0 & 50 & 47 & 3 \\
\hline 3 & 0 & 50 & 50 & 0 & 50 & 0 & 0 & 50 & 42 & 8 \\
\hline 4 & 0 & 50 & 50 & 0 & 50 & 0 & 0 & 50 & 38 & 18 \\
\hline 5 & 0 & 50 & 50 & 0 & 49 & I & 0 & 50 & 22 & 28 \\
\hline 6 & 0 & 50 & 50 & 0 & 47 & 3 & 20 & 30 & 25 & 25 \\
\hline 7 & 1 & 49 & 50 & 0 & 31 & 19 & 0 & 50 & 42 & 8 \\
\hline 8 & & & & & 3 & 47 & 3 & 47 & 41 & 9 \\
\hline 9 & & & & & 0 & 50 & 17 & 33 & 38 & 18 \\
\hline 10 & & & & & 0 & 50 & $\sqrt{44}$ & 6 & 35 & 15 \\
\hline 11 & & & & & 0 & 50 & 37 & 13 & 45 & 5 \\
\hline 12 & & & & & 0 & 50 & 26 & 24 & 44 & 6 \\
\hline 13 & & & & & 0 & 50 & 29 & 21 & 43 & 7 \\
\hline 14 & & & & & 0 & 50 & 13 & 37 & 47 & 3 \\
\hline 15 & & & & & 0 & 50 & 46. & 4 & 46 & 4 \\
\hline 16 & & & & & 0 & 50 & $\sqrt{34}$ & 176 & 50 & 0 \\
\hline 17 & & & & & 0 & 50 & 14 & 7 & 48 & 2 \\
\hline 18 & & & & & 0 & 50 & 28 & 28 & 49 & 3 \\
\hline 1.9 & & & & & 0 & 50 & $\sqrt{22}$ & 28 & 49 & 1 \\
\hline 20 & & & & & 0 & 50 & 21 & 29 & 50 & 0 \\
\hline 21 & & & & & 0 & 50 & 31 & 19 & 49 & 1 \\
\hline 22 & & & & & 0 & 50 & 134 & 116 & 49 & 7 \\
\hline 23 & & & & & & & 26 & 24 & & \\
\hline 24 & & & & & & & 121 & 129 & & 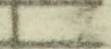 \\
\hline 25 & & & & & & & 20 & 130 & & \\
\hline 26 & & & & & & & 5 & 145 & & \\
\hline 27 & & & & & & & 110 & 140 & & \\
\hline
\end{tabular}


APPEIDIX

TABLE IV (continued)

RECORDS IN THE FOOD SITUATION

\begin{tabular}{|c|c|c|c|c|c|c|c|c|c|c|}
\hline $\begin{array}{l}\text { Obser- } \\
\text { vation }\end{array}$ & $\begin{array}{l}\text { Rat } \\
13 \\
\end{array}$ & $\begin{array}{l}\text { No. } \\
q\end{array}$ & $\begin{array}{r}\text { Rat } \\
14 \\
\end{array}$ & $\begin{array}{l}\text { No. } \\
\text { s }\end{array}$ & $\begin{array}{r}\text { Rat } \\
15 \\
\end{array}$ & $\begin{array}{l}\text { No. } \\
q\end{array}$ & $\begin{array}{r}\text { Rat } \\
16 \\
\end{array}$ & $\begin{array}{l}\overline{100} \\
\sigma^{\circ}\end{array}$ & $\begin{array}{r}\text { Ret } \\
17 \\
\end{array}$ & $\begin{array}{l}0 \\
\end{array}$ \\
\hline period & Right & Left & $1 \mathrm{ght}$ & Left & Ight & Left & & Left & & \\
\hline & 13 & 37 & 33 & 17 & 38 & 12 & 1 & 49 & 27 & 2 \\
\hline$\frac{2}{3}$ & 32 & 18 & 45 & 5 & 32 & 18 & 2 & 48 & 23 & 27 \\
\hline 3 & 28 & 22 & 42 & 8 & 30 & 20 & o & 50 & 26 & 28 \\
\hline 4 & 37 & 13 & 43 & 7 & 32 & 78 & 2 & 48 & 17 & 3 \\
\hline 5 & 11 & 39 & 42 & 8 & 23 & 27 & 8 & 42 & 26 & 24 \\
\hline$\frac{5}{6}$ & 21 & $\frac{129}{2}$ & 42 & 8 & 19 & 31 & I & 49 & 12 & \\
\hline 7 & 29 & 21 & 43 & $\overline{7}$ & 14 & 36 & 10 & 40 & 16 & 34 \\
\hline 8 & 26 & $\sqrt{24}$ & & 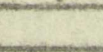 & & 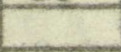 & 17 & $\sqrt{33}$ & 14 & \\
\hline 9 & 23 & 27 & & & & & & & 19 & 31 \\
\hline 10 & 28 & 22 & & & & & & & 21 & 28 \\
\hline 11 & 32 & 18 & & & & & & & 21 & 29 \\
\hline 12 & 28 & $\sqrt{22}$ & & & & & & & 14 & 36 \\
\hline 13 & 16 & 34 & & & & & & & 18 & $\sqrt{32}$ \\
\hline 14 & 26 & 24 & & & & & & & 20 & 130 \\
\hline 15 & 27 & 23 & & & & & & & 17 & $\sqrt{38}$ \\
\hline 16 & 24 & 26 & & & & & & & 12 & $\sqrt{38}$ \\
\hline 17 & 25 & & & & & & & & 19 & 31 \\
\hline 18 & & & & & & & & & 17 & $\sqrt{38}$ \\
\hline 19 & & & & & & & & & 25 & 25 \\
\hline 20 & & & & & & & & & 19 & 31 \\
\hline 23 & & & & & & & & & 21 & 129 \\
\hline 22 & & & & & & & & & 23 & 127 \\
\hline 23 & & & & & & & & & 29 & 121 \\
\hline 24 & & & & & & & & & 27 & 123 \\
\hline
\end{tabular}


APPENDIX

TABLE IV (continued)

POST-OPERATIVE RECORDS IN THE FOOD STTUATION

\begin{tabular}{|c|c|c|c|c|c|c|c|c|c|c|}
\hline $\begin{array}{l}\text { Obser- } \\
\text { vation }\end{array}$ & $\begin{array}{r}\text { Ret } \\
13 \\
\end{array}$ & $\begin{array}{l}\text { No. } \\
\text { is. }\end{array}$ & $\begin{array}{r}R a t \\
14 \\
\end{array}$ & ivo. & $\begin{array}{r}\text { Ret } \\
15 \mathrm{~g} \\
\end{array}$ & 10. & $\begin{array}{r}\text { Rat } \\
16 \\
\end{array}$ & 10: & $\begin{array}{l}R 8 t \\
17 \\
\end{array}$ & $\begin{array}{l}\text { No: } \\
\rho^{7}\end{array}$ \\
\hline period & RIght & LePt & Ight & Left & Sight & eft & RIght & Left & & \\
\hline 1 & 26 & 34 & 31 & 19 & 49 & I & 9 & 41 & 34 & 16 \\
\hline 2 & 19 & 31 & 38 & 17 & 46 & 4 & 6 & 44 & 35 & \\
\hline 3 & 16 & 34 & 31 & 19 & 36 & 24 & 32 & 18 & 38 & 117 \\
\hline 4 & 19 & 81 & 24 & 26 & 41 & 9 & 45 & 5 & 38 & 17 \\
\hline 5 & 13 & 37 & 88 & 22 & 43 & 7 & 49 & 1 & 39 & $\pi$ \\
\hline 6 & 1 & 47 & 25 & 25 & 49 & 1 & 43 & 7 & 17 & 33 \\
\hline 7 & 9 & 41 & 19 & 31 & 49 & $I$ & 33 & 17 & 28 & 22 \\
\hline 8 & 17 & 85 & 14 & 36 & 47 & 5 & 40 & 10 & 13 & 3 \\
\hline 9 & 10 & 40 & 8 & 42 & 46 & 4 & 18 & 32 & 30 & 20 \\
\hline 10 & 19 & 31 & 9 & 41 & 47 & 3 & 40 & 10 & 34 & 16 \\
\hline 11 & 9 & 41 & 3 & 47 & 50 & 0 & 26 & $\sqrt{24}$ & 19 & 37 \\
\hline 12 & 11 & 39 & 10 & 40 & & & 40 & 10 & 26 & Iz \\
\hline 13 & 3 & 47 & 19 & 31 & & & 40 & 10 & 46 & \\
\hline 14 & 9 & 41 & 25 & 25 & & & 37 & 13 & 36 & 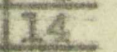 \\
\hline 15 & 18 & 38 & 34 & 16 & & & 40 & 10 & 39 & 11 \\
\hline 16 & 13 & 37 & 29 & 21 & & & 39 & 21 & 36 & 114 \\
\hline 17 & 22 & 28 & 33 & 177 & & & 37 & 13 & 34 & 6 \\
\hline 18 & 13 & 37 & 31 & 19 & & & 40 & 10 & & \\
\hline 19 & 21 & 29 & 27 & 23 & & & & & & \\
\hline 20 & 12 & 38 & 19 & 31 & & & & & & \\
\hline 21 & 17 & 38 & 12 & 38 & & & & & & \\
\hline 22 & 15 & 85 & 18 & 32 & & & & & & \\
\hline 23 & 10 & 40 & 81 & 29 & & & & & & \\
\hline 24 & & & 22 & 128 & & & & & & \\
\hline 25 & & & 16 & 34 & & & & & & \\
\hline 26 & & & 18 & 138 & & & & & & \\
\hline 27 & & & 13 & 137 & & & & & & \\
\hline
\end{tabular}


APPENDIX

TABLE IV (continued)

RECORDS IN THE FOOD SITUATION

\begin{tabular}{|c|c|c|c|c|c|c|c|c|c|c|}
\hline $\begin{array}{l}\text { Obser- } \\
\text { vation }\end{array}$ & $\begin{array}{r}\text { Ret } \\
18 \\
\end{array}$ & $\begin{array}{l}\text { No. } \\
q\end{array}$ & $\begin{array}{r}\text { Rat } \\
19 \\
\end{array}$ & $\begin{array}{l}\text { To. } \\
\text { 9. }\end{array}$ & $\begin{array}{r}\text { Rat } \\
20\end{array}$ & $\begin{array}{l}\text { No. } \\
\text { की }\end{array}$ & $\begin{array}{r}\text { Ret } \\
21\end{array}$ & $\begin{array}{l}\text { No. } \\
\text { q }\end{array}$ & $\begin{array}{r}\text { Ret } \\
22\end{array}$ & $\begin{array}{l}\text { No. } \\
0^{1}\end{array}$ \\
\hline period & R1ght & Ireft & gight & Left & 1ght & Left & Right & Ineft & Right & Leet \\
\hline 3 & 50 & 0 & 4 & 46 & 31 & 19 & 50 & 0 & 44 & 6 \\
\hline 2 & 48 & 2 & 0 & 50 & 14 & 36 & 47 & 3 & 49 & 1 \\
\hline 3 & 42 & 3 & 1 & 49 & 40 & 10 & 48 & 2 & 50 & 0 \\
\hline 4 & 49 & 1 & 0 & 50 & 48 & 2 & 50 & 0 & 49 & 1 \\
\hline 5 & 48 & 8 & 1 & 49 & 44 & 6 & 50 & 0 & 50 & 0 \\
\hline 6 & 42 & 8 & 0 & 50 & 36 & 36 & 48 & 2 & 50 & 0 \\
\hline 7 & 48 & है & 1 & 19 & 40 & 10 & 48 & 7 & 50 & 0 \\
\hline 8 & 50 & 0 & & & 43 & 7 & 50 & 0 & 46 & 4 \\
\hline 9 & 47 & 3 & & & 42 & 8 & & & 47 & 3 \\
\hline 10 & & & & & 43 & 7 & & & 50 & 0 \\
\hline 11 & & & & & 48 & 2 & & & 50 & 0 \\
\hline 28 & & & & & 49 & 1 & & & 50 & 0 \\
\hline 13 & & & & & 46 & 4 & & & 49 & 1 \\
\hline 14 & & & & & 49 & 3 & & & 50 & Q \\
\hline 15 & & & & & 50 & 0 & & & 50 & 0 \\
\hline 16 & & & & & 45 & 5 & & & & \\
\hline
\end{tabular}


APPEIVIX

TABLE IV (cont1nued)

POST-OPERATIVE RECORDS IN THE FOOD SITUATION

\begin{tabular}{|c|c|c|c|c|c|c|c|c|c|c|}
\hline $\begin{array}{l}\text { Obser- } \\
\text { vation }\end{array}$ & $\begin{array}{r}\text { Rat } \\
18 \\
\end{array}$ & W0. & $\begin{array}{r}\text { Rat } \\
19 \\
\end{array}$ & $\begin{array}{l}10 . \\
\text { io. }\end{array}$ & $\begin{array}{r}\text { Rat } \\
20 \\
\end{array}$ & $\begin{array}{l}\text { No. } \\
\sigma^{10}\end{array}$ & $\begin{array}{r}\text { Ret } \\
21 \\
\end{array}$ & $\begin{array}{l}\text { No: } \\
q\end{array}$ & $\begin{array}{r}\text { Rat } \\
28 \\
\end{array}$ & ה10. \\
\hline$\frac{\text { period }}{1}$ & $\frac{\text { Right }}{43}$ & eft & glght & Left & RIght & Lert & Right & Left & Right I & Left \\
\hline$\frac{1}{2}$ & $\frac{43}{2}$ & 7 & $\frac{16}{5}$ & $\frac{34}{15}$ & $\frac{44}{50}$ & $\frac{6}{6}$ & $\frac{50}{50}$ & $\frac{0}{0}$ & $\frac{50}{50}$ & $\frac{0}{0}$ \\
\hline 3 & 13 & $\frac{40}{37}$ & $\frac{3}{9}$ & $\frac{45}{47}$ & $\frac{50}{47}$ & $\frac{0}{3}$ & $\frac{50}{49}$ & $\frac{4}{1}$ & 50 & $\frac{\pi}{0}$ \\
\hline 4 & 34 & 26 & 8 & 42 & 49 & 1 & 49 & I & 50 & $\frac{\pi}{0}$ \\
\hline 5 & 32 & 18 & 7 & 43 & 48 & $\sqrt{2}$ & 48 & 2 & 50 & 0 \\
\hline 6 & 45 & 5 & 8 & 42 & 48 & 2 & 49 & 1 & 50 & 0 \\
\hline 7 & 36 & 14 & 6 & 44 & 47 & 3 & 50 & 0 & 50 & 0 \\
\hline 8 & 33 & 17 & 13 & 37 & 50 & 0 & 50 & 0 & 50 & 0 \\
\hline 9 & $\frac{35}{2}$ & 15 & 10 & 40 & 48 & 2 & 50 & 0 & 50 & 0 \\
\hline 10 & 34 & 16 & 12 & 38 & 49 & I & 50 & 0 & & \\
\hline 11 & 40 & 10 & & & 50 & 0 & & & & \\
\hline 12 & 35 & 15 & & & & & & & & \\
\hline 13 & 42 & 8 & & & & & & & & \\
\hline 14 & 40 & 20 & & & & & & & & \\
\hline 15 & 34 & 16 & & & & & & & & \\
\hline 26 & 37 & 13 & & & & & & & & \\
\hline 17 & 22 & 28 & & & & & & & & \\
\hline 18 & 39 & 11 & & & & & & & & \\
\hline 19 & 40 & 10 & & & & & & & & \\
\hline 20 & 39 & 11 & & & & & & & & \\
\hline 21 & 37 & 13 & & & & & & & & \\
\hline
\end{tabular}




\section{APPENDIX}

\section{TABLE IV (continued)}

RECORDS IN THE FOOD SITUATION

\begin{tabular}{|c|c|c|c|c|c|c|c|c|c|c|}
\hline $\begin{array}{l}\text { Obser- } \\
\text { vation }\end{array}$ & $\begin{array}{r}\text { Rat } \\
23 \\
\end{array}$ & 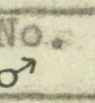 & $\begin{array}{r}\operatorname{Rat} \\
84 \\
\end{array}$ & ro. & $\begin{array}{r}\text { Ret } \\
85 \\
\end{array}$ & $\begin{array}{l}\text { No. } \\
\text { q. }\end{array}$ & $\begin{array}{r}\text { Rat } \\
26 \\
\end{array}$ & $\begin{array}{l}10 . \\
9 \\
\end{array}$ & $\begin{array}{r}R E t \\
27 \\
\end{array}$ & $\begin{array}{l}\text { No. } \\
\text { f }\end{array}$ \\
\hline clod & & eft & & eft & & Left & gight & eft & & \\
\hline 1 & 50 & 0 & 40 & 10 & 0 & 50 & 46 & 2 & 45 & \\
\hline 2 & 50 & 0 & 19 & 31 & 0 & 50 & 45 & 5 & 47 & \\
\hline 3 & 50 & 0 & 7 & 43 & 1 & 49 & 46 & 4 & 50 & 0 \\
\hline$\frac{\pi}{4}$ & 50 & 0 & 41 & 9 & o & 50 & 48 & $\frac{1}{2}$ & 46 & \\
\hline 5 & 50 & 0 & 44 & 6 & 0 & 50 & 50 & 0 & 43 & \\
\hline 6 & 49 & $\frac{1}{1}$ & 46 & 4 & 0 & 50 & 50 & 0 & 50 & 0 \\
\hline 7 & 50 & 0 & 45 & 5 & 0 & 50 & 50 & 0 & 46 & \\
\hline 8 & 48 & 2 & 49 & 1 & 0 & 50 & 48 & $\overline{2}$ & 48 & \\
\hline 9 & 50 & 0 & 50 & 0 & 0 & 50 & 50 & 0 & 47 & \\
\hline 10 & 50 & 0 & 50 & 0 & 0 & 50 & 49 & I & 46 & \\
\hline 12 & 37 & 13 & 50 & 0 & 0 & 50 & 50 & 0 & 48 & \\
\hline 12 & 39 & 11 & 50 & 0 & 1 & 49 & 49 & 1 & 48 & \\
\hline 13 & 47 & 3 & 50 & 0 & 0 & 50 & 50 & 0 & 49 & \\
\hline 1.4 & 50 & 0 & 50 & 0 & 0 & 50 & 50 & 0 & 49 & \\
\hline 15 & 50 & 0 & 50 & 0 & 0 & 50 & .48 & 2 & 49 & \\
\hline 16 & 50 & 0 & 50 & 0 & 0 & 50 & & & & \\
\hline 17 & 50 & 0 & 50 & 0 & 0 & 50 & & & & \\
\hline 18 & 50 & 0 & 50 & 0 & 1 & 49 & & & & \\
\hline 19 & 50 & 0 & 50 & 0 & 0 & 50 & & & & \\
\hline 20 & 50 & 0 & 48 & 2 & & & & & & \\
\hline 21 & 50 & 0 & 49 & & & & & & & \\
\hline 22 & 50 & 0 & 49 & 1 & & & & & & \\
\hline 23 & 49 & 1 & 50 & 0 & & & & & & \\
\hline 24 & 50 & 0 & & & & & & & & \\
\hline 25 & 50 & 0 & & & & & & & & \\
\hline
\end{tabular}




\section{APPENDIX}

TABIE IV (continued)

POST-OPERATIVE RECORDS II THE FOOD SITUATION

\begin{tabular}{|c|c|c|c|c|c|c|c|c|c|c|}
\hline $\begin{array}{l}\text { Obser- } \\
\text { vetion }\end{array}$ & $\begin{array}{r}\text { Rat } \\
28 \\
\end{array}$ & $\begin{array}{l}10 . \\
9^{2}\end{array}$ & $\begin{array}{r}\mathrm{Ret} \\
24 \\
\end{array}$ & $\begin{array}{l}\text { No. } \\
0^{7}\end{array}$ & $\begin{array}{r}\text { Rat } \\
25 \\
\end{array}$ & $\begin{array}{l}\text { No. } \\
\text { q0 }\end{array}$ & $\begin{array}{r}\text { Rat } \\
26 \\
\end{array}$ & $\begin{array}{l}\text { No. } \\
\text { 早 }\end{array}$ & $\begin{array}{r}\text { Ret } \\
27 \\
\end{array}$ & $\begin{array}{l}\text { No: } \\
9\end{array}$ \\
\hline period & Rlght & Left & 3ight & feft & ight & Geft & Right & Geft & K1ght & Geft \\
\hline 3 & 50 & 0 & 50 & 10 & 0 & 50 & 50 & a & 48 & 2 \\
\hline 2 & 50 & 0 & 50 & o & 0 & 50 & 50 & 0 & 48 & 2 \\
\hline 3 & 50 & 0 & 50 & 0 & 0 & 50 & 50 & 0 & 45 & 5 \\
\hline 4 & 50 & 0 & 50 & 10 & 0 & 50 & 50 & 0 & 47 & 3 \\
\hline 5 & 50 & 0 & 50 & 10 & 0 & 50 & 50 & 0 & 48 & 2 \\
\hline 6 & 50 & 0 & 50 & 10 & 0 & 50 & 50 & 0 & 48 & 2 \\
\hline 7 & 50 & 0 & 50 & 10 & 0 & 50 & 50 & 0 & 49 & 1 \\
\hline 8 & 50 & 0 & 50 & 10 & 0 & 50 & 50 & 0 & 50 & 0 \\
\hline 9 & 50 & 0 & 50 & 0 & 0 & 50 & 50 & 0 & 50 & 0 \\
\hline 10 & 50 & 0 & 50 & $\frac{1}{0}$ & 0 & 50 & 50 & 0 & 50 & 0 \\
\hline 11 & 49 & I. & 50 & 0 & 3 & 49 & 50 & 0 & 49 & 1 \\
\hline 12 & & & & & 0 & 50 & & I & & \\
\hline
\end{tabular}


APPEIDTX

TABLE IV (continued)

RECORDS IN THE FOOD STTUATION

\begin{tabular}{|c|c|c|c|c|}
\hline $\begin{array}{l}\text { Obser- } \\
\text { vation }\end{array}$ & $\begin{array}{r}\text { Ret } \\
28 \\
\end{array}$ & $\begin{array}{l}110 . \\
0^{7}\end{array}$ & $\begin{array}{r}\text { Ret } \\
29\end{array}$ & $\begin{array}{l}100 \\
\sigma^{\circ}\end{array}$ \\
\hline period & Right & Lert & Right & Reft \\
\hline 3 & 49 & 1 & 31 & 19 \\
\hline 2 & 48 & 2 & 2 & 48 \\
\hline 3 & 46 & 4 & $\frac{7}{7}$ & 43 \\
\hline 4 & 42 & 8 & 20 & 30 \\
\hline 5 & 29 & 21 & 17 & 83 \\
\hline 6 & 8 & 42 & 21 & 29 \\
\hline 7 & 43 & 7 & 29 & 21 \\
\hline 8 & 41 & 9 & 11 & 39 \\
\hline 9 & 89 & 11 & 12 & 38 \\
\hline 10 & & & $\frac{1}{2}$ & 48 \\
\hline 37 & & & 1 & 19 \\
\hline 12 & & & 2 & 48 \\
\hline 13 & & & 5 & 45 \\
\hline 14 & & & 3 & 47 \\
\hline 15 & & & 20 & 30 \\
\hline 16 & & & 2 & 48 \\
\hline 17 & & & 6 & 44 \\
\hline 18 & & & 1.8 & 37 \\
\hline 29 & & & 5 & 45 \\
\hline 20 & & & 7 & 43 \\
\hline 21 & & & d & 50 \\
\hline 32 & & & 3 & 47 \\
\hline 23 & & & 1 & 49 \\
\hline 84 & & & 0 & 50 \\
\hline
\end{tabular}


APPENDIX

TABLE IV (continued)

POST-OPERATIVE RECORDS IN THE FOOD STTUATION

\begin{tabular}{|c|c|c|c|c|}
\hline $\begin{array}{l}\text { Obser- } \\
\text { vation }\end{array}$ & $\begin{array}{r}R e t \\
28 \\
\end{array}$ & $\begin{array}{l}\text { No. } \\
r^{7}\end{array}$ & $\begin{array}{r}\text { Ret } \\
29 \\
\end{array}$ & No. \\
\hline period & Ight & Left & Ight & Left \\
\hline 1 & 45 & 5 & 1 & 49 \\
\hline 2 & 35 & 15 & 3 & 47 \\
\hline 3 & 48 & 2 & 1 & 49 \\
\hline 4 & 50 & 0 & 0 & 50 \\
\hline 5 & 50 & 0 & 2 & 148 \\
\hline 6 & 46 & 4 & 3 & 47 \\
\hline 7 & 54 & 6 & 1 & 49 \\
\hline 8 & 50 & 0 & 2 & 48 \\
\hline 9 & 50 & 0 & 3 & 49 \\
\hline 10 & 50 & 0 & 0 & 50 \\
\hline 11 & 50 & 0 & 0 & 50 \\
\hline 18 & 50 & 0 & & \\
\hline 13 & 5 & 0 & & \\
\hline 14 & 6 & 4 & & \\
\hline 15 & 7 & 6 & & \\
\hline
\end{tabular}






\section{MMPORTANTI:}

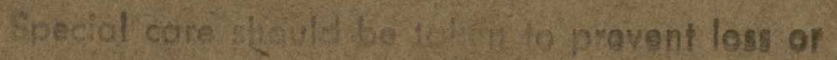

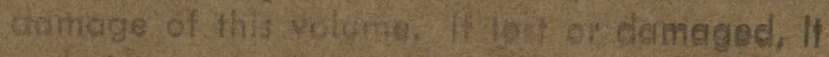
fust be poid for of thateuram rate of tyaing.

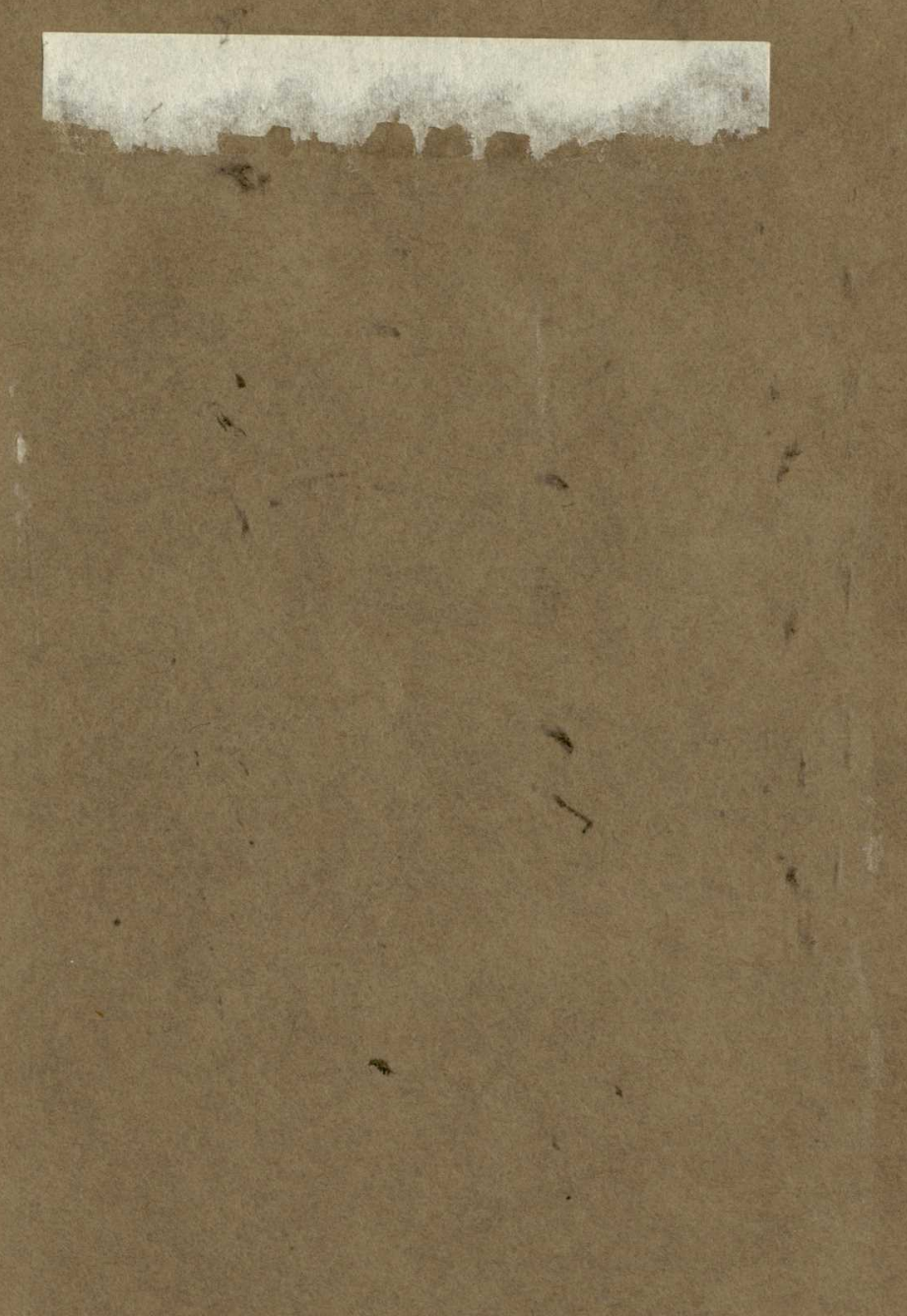




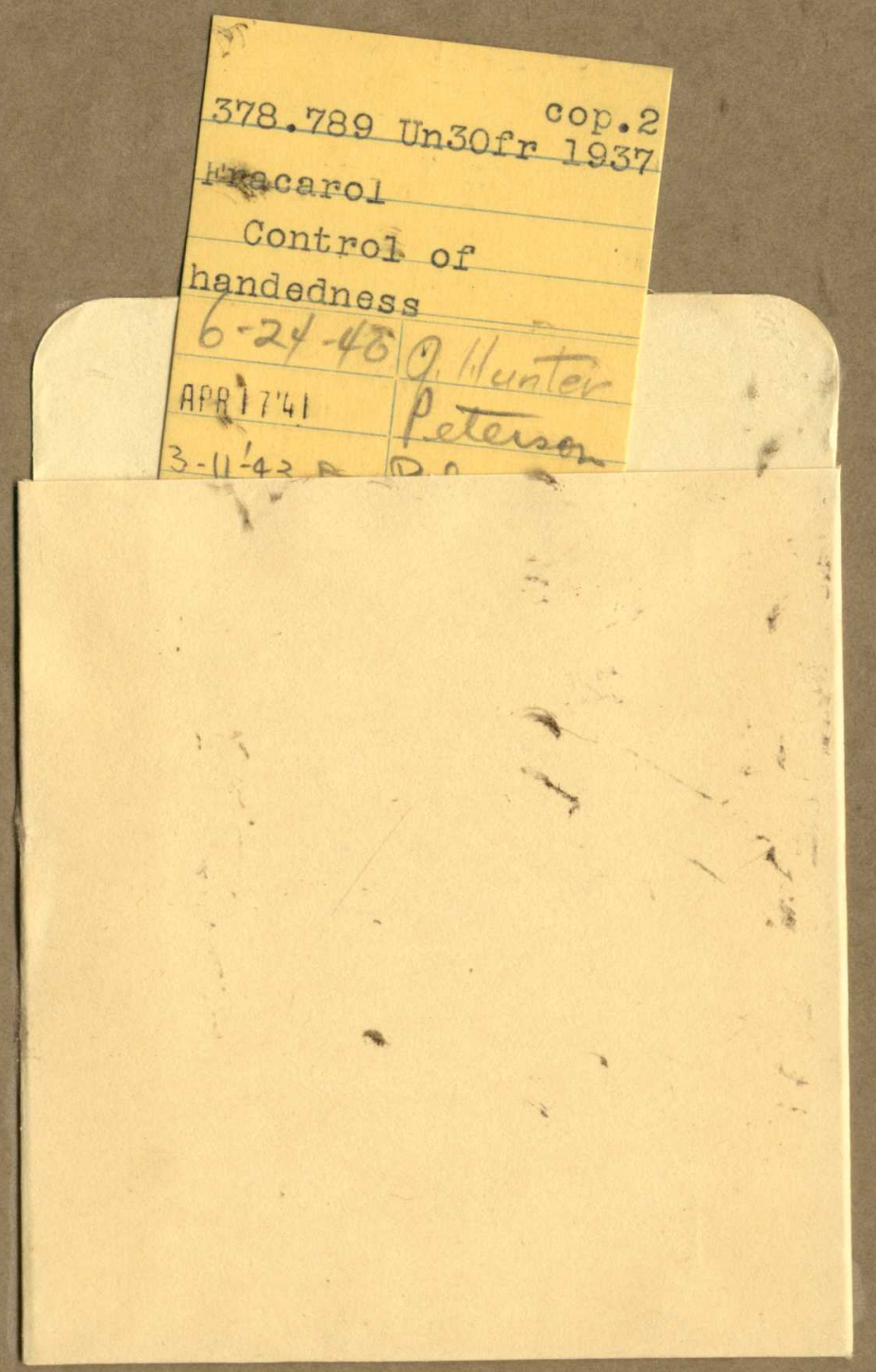




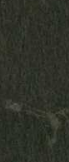

3

X.

(x)
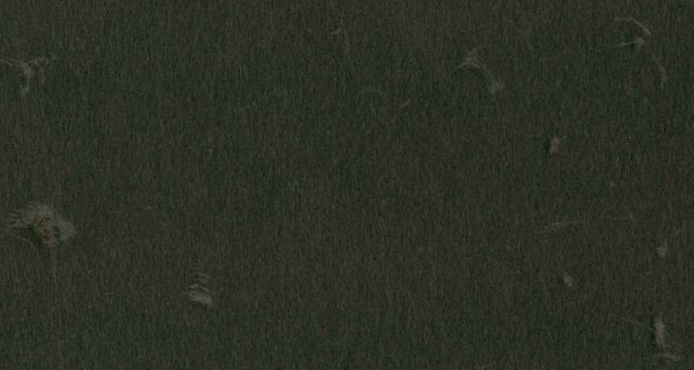

-
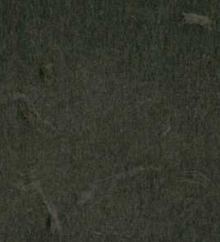